\title{
Maaseudun ja kaupungin vuorovaikutus osana kestävyysmuutosta
}

\author{
Torsti Hyyryläinen, Juha Helenius, Kaisa Schmidt-Thomé, Aapo \\ Jumppanen ja Manu Rantanen
}

Kestävyysmuutoksella tarkoitamme yhteiskunnallista muutosta, joka suuntautuu kestävän kehityksen tavoitteiden mukaisesti ihmisen ja luonnon yhteisen hyvinvoinnin toteutumiseen yhteiskunnassa. Näiden tavoitteiden saavuttaminen edellyttää poliittisia päätöksiä sekä systeemitason ratkaisuja. Kaupunkeja ja maaseutuja yhdistävä ongelma on: miten ihmisen ja luonnon suhde saadaan tasapainoon? Suhde luontoon on kaupungeissa erilainen kuin maaseuduilla, mutta ongelmaton se ei ole missään. Maaseudun ja kaupungin tasapainoisempi vuorovaikutus voidaan nähdä osana kestävyysmuutosta.

Maaseudun ja kaupungin vuorovaikutusta muokkaa keskeisesti talouden globaali vaihdantajärjestelmä. Sen reunaehdot ovat kuitenkin muuttumassa. Jos ekologinen jälleenrakennus ja uudenlainen talousjärjestelmä toteutuvat, muuttuu myös yhteiskunnan tilallinen järjestys.

DOI: $10.51807 /$ maaseutututkimus. 112891 
$\mathrm{M}$ aaseudun ja kaupungin elävä suhde tarkoittaa ensinnäkin, että kaupungit ja maaseudut ovat elinympäristöinä ja kerronnallisina kuvastoina erilaisia, mutta toiminnallisesti toisiinsa monin tavoin kytkeytyneitä. Maaseudun ja kaupungin suhteessa on historiallisesti muovautuneita, suhteellisen pysyviä piirteitä, mutta siinä on myös monia ajassa muuttuvia tekijöitä.

Talouden globaali vaihdantajärjestelmä on keskeisesti maaseudun ja kaupungin vuorovaikutusta muokkaava asia. Talouden reunaehdot näyttävät kuitenkin olevan muutoksessa: "On aivan mahdollista, että koemme tulevina vuosikymmeninä sellaisia muutoksia, jotka muuttavat rajusti ymmärrystä taloudesta, sen suhteesta paikkoihin ja myös ihmisten käyttäytymisestä ja valinnoista. Silloin muuttuu moni muukin asia.” (Koste ym. 2020, 15) Jos ekologinen jälleenrakennus ja uudenlainen talousjärjestelmä todella toteutuvat, muuttuu myös yhteiskunnan tilallinen järjestys.

Kestävyysmuutoksella tarkoitamme yhteiskunnallista muutosta, joka suuntautuu kestävän kehityksen tavoitteiden mukaisesti ihmisen ja luonnon yhteisen hyvinvoinnin toteutumiseen yhteiskunnassa. Näiden tavoitteiden saavuttaminen edellyttää poliittisia päätöksiä sekä systeemitason ratkaisuja. Kaupunkeja ja maaseutuja yhdistävä ongelma on: miten ihmisen ja luonnon suhde saadaan tasapainoon? Suhde luontoon on kaupungeissa erilainen kuin maaseuduilla, mutta ongelmaton se ei ole missään. Maaseudun ja kaupungin tasapainoisempi vuorovaikutus voidaan nähdä osana kestävyysmuutosta - tienä kohti kestävämpää maailmaa.

\section{Kaupunkien ja maaseutujen vuorovaikutuksen kerron- nallinen rakentuminen}

Kaupungeilla ja maaseuduilla on sekä aineellinen (fyysinen) puolensa että sosiaalisesti tuotettu kerronnallinen todellisuutensa, ja ne tulevat ymmärretyiksi vain suhteessa toisiinsa. Toisin sanoen sekä maaseutu että kaupunki määrittyvät toisistaan ja edellyttävät toisiaan niin fyysisinä kuin kerronnallisina entiteetteinä. Näin ajateltuna tuo vuorovaikutus on elävä suhde, joka reagoi ajassa ja tilassa yhteiskunnalliseen kehitykseen.

Suomen kieleen maaseudun käsite vakiintui 1800-1900 -lukujen taitteessa, paljon myöhemmin kuin sana kaupunki. Laajempi tarve maaseudun käsitteeseen syntyi modernien kaupunkien synnyn ja kasvun 
myötä. Näin voitiin yleisesti kuvata kaupunkien ulkopuolisia alueita. Molemmat käsitteet muuttuvat hyvin hitaasti. Ne yleistävät kohteensa ja kuvaavat kohdettaan abstraktilla tavalla. Näin ne ovat alttiita kilpaileville tulkinnoille ja jännitteille, joita myös eri syistä tarkoituksellisesti ylläpidetään. Niin kaupungin kuin maaseudun yksiselitteinen määrittely on tutkimuksenkin piirissä vaikeata. Hallinnon, tilastoinnin ja politiikan tarpeisiin on kuitenkin luotu erilaisia määritelmiä, jotka erottavat kaupungit ja maaseudut maantieteellisinä kokonaisuksina toisistaan.

Diskursiivisesti tuotetut merkitykset ja käsitykset esimerkiksi maaseudun olemuksesta muovaavat väistämättä myös fyysistä maailmaa: ihminen muokkaa ympäristöään, niin kaupunkeja kuin maaseutuja tarpeidensa ja tavoitteidensa mukaisesti käyttämällä luovuuttaan ja hyödyntämällä teknologiaa. Näin syntyy erilaisia paikallisuuksia, toimintaympäristöjä erilaisille toiminnan- ja elämäntavoille.

Erilaiset paikallisuudet kutoutuvat ihmisten identiteetteihin, nykyisin ohi perinteisten kaupunkilaisuus tai maalaisuus -määrittelyjen. Paikkaan sitoutuvat identiteetit, sekä toimijan itsensä että yhteisön häneen kohdistamina määrittelyinä, muuttuvat ihmisten liikkuessa erilaisten paikkojen välillä. Esimerkiksi käy henkilö, joka elää sekä maaseudulla että kaupungissa. Kaupungissa arvioitavana voi olla hänen "stadilaisuutensa", mutta mökillä asuessaan sama henkilö voidaan nähdä yleisesti kaupunkilaisena, mökkiläisenä tai etätyöläisenä.

Monipaikkaisesti elävät ihmiset ilmentävät konkreettisesti kaupungin ja maaseudun välistä uudistuvaa vuorovaikutusta. Heidän erilaiset paikkakokemuksensa ja niihin liittyvät tulkintansa saattavat poiketa paljonkin monipaikkaisen asumisen mediajulkisuudesta, jota leimaa usein aiheeseen liittyvät poliittiset pyrkimykset. Monipaikkaisille asukkaille on jo pitkään tarjottu välittäjäroolia maaseudun ja kaupungin välille, ja heidän taloudellista merkitystään maaseudulla korostetaan. Arjen tasolla he eivät välttämättä miellä itseään ensisijaisesti kaupunkilaisiksi tai maalaisiksi, vaan kiinnittyvät heille tärkeisiin paikkoihin tunnesitein, jotka usein vahvistuvat ajan myötä.

Digitaalinen kehitys, työelämän muutokset ja ajankohtainen, maailmanlaajuinen Covid-19-pandemia ovat johtaneet aiemmin selvärajaisen, työja vapaa-ajan sekä eri paikkojen välille jakautuneen tila-aika syklin muuntumiseen, kun työtä on mahdollista tehdä niin kotona, työpaikalla kuin mökillä. Miten tämä työroolin yhdistyminen vapaa-aikaan muuttaa 
monipaikkaisten ihmisten asennetta, paikallisidentiteettiä ja toimintatapoja? Minkälaisia vaikutuksia sillä tulee olemaan maaseudun ja kaupungin vastakkainasetteluun?

\section{Maaseudun ja kaupungin suhde elävänä keskusteluna}

Vaikka ajatus maaseutujen ja kaupunkien suhteiden monimuotoisuudesta, sekoittumisesta ja eräänlaisesta hybridisyydestä alkaakin olla suhteellisen laajasti tunnistettu myös tutkijapiirien ulkopuolella, julkisessa keskustelussa ja mielikuvien tasolla maaseudun ja kaupungin vastakkaisuus on edelleen itseään uusintava maaseudun ja kaupungin suhteen kerronnallinen piirre.

Eri medioissa asioiden esittäminen kaupungin ja maaseudun ristiriitana tai konfliktina on toiminut kautta historian hyvin, koska sillä voidaan kiinnittää suuren yleisön huomio. Politiikassa toiseutta rakennetaan tietoisesti, osana valtakamppailua ja erottautumisena muista. Maaseudun ja kaupungin vastakkainasettelulla voi edelleen profiloitua ja edistää poliittisen tai taloudellisen intressiryhmän yhteiskunnallisia tavoitteita.

Maaseudun ja kaupungin ihmiset asemoidaan vastakkaisiksi osapuoliksi esimerkiksi energia- ja ilmastokysymyksiä, maahanmuuttoa, luonnon ja eläinten suojelua tai kansallisen identiteetin rakentamista koskevissa keskusteluissa. Usein näissä keskustelussa viitataan ihmisiin yleisesti kaupunkilaisina tai maaseudun asukkaina, vaikka nämä ryhmät ovat hyvin epäyhtenäisiä. Myytti yhden kulttuurin Suomesta on tässäkin suhteessa murtumassa (vrt. Tervonen 2014).

Lehtien kirjoituksissa ja mielipidepalstojen kommenteissa voidaan esittää, että kaupunkilaisten tulee kylmä ja nälkä ilman maalaisia, tai että kaupunkilaisten luontosuhde on vääristynyt, ja siksi mm. viljelyyn, metsänhoitoon, suurpetoihin, turpeeseen jne. liittyvät kysymykset tulisikin jättää maalaisten hoidettaviksi. Toisaalta yhtä lailla maalaisia voidaan kuvata väärässä oleviksi kehityksen jarruiksi. Maaseudun ja kaupungin sekä niiden asukkaiden olemuksesta käydäänkin mediassa retorista varjonyrkkeilyä, jossa vastustajan julkituodut ja oletetut väitteet pyritään osoittamaan pätemättömiksi. (Esim. Appelsin 2021; Maaseutu ei ole kehityksen jarru 2015; Rummukainen 2015; Pelkonen 2018; Enbuske 2017a-b) 
Julkisissa puheenvuoroissa Suomi jaetaan toisinaan myös pääkaupunkiseutuun ja maakuntiin, aivan kuin muulla Suomella olisi yhteneväiset, maaseutumaiset intressit. Puoluepolitiikka tuo keskusteluun oman kerroksensa. Keskustalainen ministeri voi puhua julkisuudessa "talonpoikaisesta taloudenpidosta". Vastapuolella puhutaan esimerkiksi "kepun iltalypsystä" tai "kepulandiasta". (Mm. Junkkari 2020, A3; Pääkaupunkiseutu elättää muun Suomen 2009; Poranen 2013, 75-76; Enbuske 2017a; Saarikko puoluevaltuustossa: Hyvä taloudenpito hallituksen tärkein tehtävä 2020; Koivula 2021; Karvala 2015; Eerola 2021)

Vastakkainasettelut nousevat julkisuuteen nopeasti yhteiskuntaa koettelevien äkillisten muutosten, sokkien vaikutuksesta. Ajankohtaisena esimerkkinä voidaan mainita koronapandemian rajoitustoimena pääkaupunkiseudun ja muun Suomen välille valtiovallan toimesta 2020 toteutetut liikkumisrajoitukset pääkaupunkiseudulta muualle Suomeen. Ne nostattivat tunteita, ja sosiaalisessa mediassa maaseudun asukkaiden ja pääkaupunkiseudun ihmisten vastakkainasettelu nousi kärkevästi esiin. Mökeille matkustaneita vapaa-ajan asukkaita loukkasi syvästi joidenkin paikallisten esiin nostama syyttely elitistisistä kaupunkilaisista vapaaajan asukkaista, jotka eivät malta pysyä epidemian riivaamalla kotiseudullaan.

Toki ääripäiden väliin mahtuu myös sovittelevia näkökantoja, joiden mukaan maaseudun ja kaupungin välille ei tulisi tarpeettomasti rakentaa jännitteitä, koska molempia tarvitaan. (Esim. Maaseutu ei ole kehityksen jarru 2015; Haapamatti 2015; Pelkonen 2018) Yhteiskunnan kaupungistumisesta huolimatta maaseutuun identifioituminen ja positiiviset maaseutumielikuvat elävät edelleen vahvoina suomalaisten keskuudessa, minkä vuoden 2020 maaseutubarometrikin osoitti (Pyysiäinen \& Vihinen 2020, 5-8, 12-13). Sovittelevat näkökannat jäävät kuitenkin mediassa usein tunteita herättävää vastakkainasettelua pienemmälle huomiolle.

Maaseudunja kaupungin suhde kytkeytyy paikkojen politiikkaan (Masuda \& Garvin 2008). Molemmat entiteetit muodostuvat käytännössä hyvin erilaisista paikoista, joiden välillä on riippuvuuden ja yhteistyön lisäksi myös aitoa kilpailua. Yhteiskunnan erilaisten toimintojen maantieteellinen sijoittuminen, tai sen valmistelu, synnyttää jännitteitä ja kiistoja paikkojen välillä: mihin esimerkiksi jokin investointi, kuten yritys tai sen toiminto voisi sijoittua? Myös kuntien kilpailu asukkaista tai osaajista synnyttää erottautumiseen pyrkivää retoriikkaa paikkakuntien esitellessä 
vetovoimatekijöitään. Näillä mielikuvamarkkinoilla luonnonläheinen maaseutu sekä sykkivä kaupunki asettuvat usein vastakkaisiksi tarinoiksi.

Paikallisuudet kaupungeissa ja maaseuduilla ovat muovautuneet ihmisen toimesta joksikin muuksi kuin "koskematon luonto". Kaikkialla ihmistoiminnan olisi kuitenkin otettava huomioon luonnon asettamat rajat. Luontosuhde kuvataan maaseudulla yleensä läheisemmäksi ja kaupunkiympäristöä luonnehditaan luonnosta etääntyneeksi, ihmisen luomien tekomuotojen dominoimaksi elinympäristöksi. Todellisuudessa tilanne ei kuitenkaan ole näin mustavalkoinen. Biosfäärin kannalta kestämätöntä toimintaa voi ilmetä niin maaseuduilla kuin kaupungeissa, ja ratkaisujakin on löydyttävä molemmista suunnista. Kysymys on pitkälti elämäntavoista, tuotantojärjestelmistä ja mittakaavasta, eli siitä, miten yhteiskunta kokonaisuutena asettuu luonnon kantokyvyn rajoihin. Tämän ongelman ratkaiseminen vaatii myös yhteiskunnan tilallisen järjestyksen uudistamista.

\section{Kestävyysmuutos maaseudun ja kaupungin vuorovaikutuksena}

Kaupungistuminen liittyy talousjärjestelmämme perustekijöihin. Suurimmat kaupunkiseudut kasvavat palveluihin ja korkeaan osaamiseen nojaavassa globaalissa talousjärjestelmässä, eikä edes suurilla vastakarvaan suuntaavilla politiikkatoimilla ole pystytty tätä suuntaa muuttamaan. Toisaalta kaikkialla maailmassa kaupungistumista on tarkoituksellisesti tuettu talouskasvun moottorina, ja se kytkeytyy valtioiden sekä alueiden talouskasvua ja innovaatioita vauhdittaviin politiikkoihin (Moisio 2018). Kaupunkiseutujensa kautta myös Suomi on haluttu kytkeä kansainväliseen tietointensiiviseen talouteen.

Kaupunkeihin ja kaupunki-infrastruktuuriin tehtävillä investoinneilla haetaan yleensä parempaa tuottavuutta. Investoinnit kaupunkirakentamiseen ovat myös suora talouskasvun lähde: rakentamisen, rakennetun ympäristön ylläpidon ja kiinteistöalan klusteri on merkittävä työllistäjä Suomessa (Rakennusteollisuus 2021). Mikäli talouden reunaehdot ja politiikan kasvuorientaatio pysyvät samoina, maaseudun ja kaupungin suhde ei tasapainoitu. Vallitseva lähtökohta politiikassa ja suurelta osin myös kestävyysmuutoksia tarkastelevassa tutkimuksessa on talouskasvu, jossa on vahvana perinteinen, dualistinen jako yhtäältä ihmisiin ja yhteiskuntiin sekä niiden hyvinvointiin, ja toisaalta luontoon ja ympäristöön 
ammennettavina resursseina tai paikkoina, joihin esimerkiksi jätteitä voi sijoittaa.

Globaalisti kaupungistumisen keskeinen muoto on metropolisoituminen, eli väestön painopisteen siirtyminen hyvin suuriin kaupunkikeskittymiin. YK:n mukaan miljoonakaupunkeja on maailmassa jo lähes 6oo, joista yli 10 miljoonan asukkaan keskittymiä on 34 (UN Habitat 2020). Mitä isompi metropoli on, sitä vähemmän se voi tukeutua vain läheiseen ympäristöönsä. Suurkaupunkien vaikutus on aina paljon laajempi, jopa maailmanlaajuinen. Riippumattomuus läheisestä ympäristöstä on suoraan verrannollista riippuvuuteen globaaleista resursseista, tuotteista ja palveluista. Metropolien näennäinen riippumattomuus biosfäärin elämää ylläpitävistä ekosysteemeistä ja paikallisista luonnonvaroista onkin se sokea piste, johon kestävän kehityksen haaste suurissa kaupungeissa etenkin ekologisessa mielessä pitkälti kulminoituu.

Keskimääräinen metropoliasukas edellyttää kaupunkiin saatavan noin puoli tonnia ruokaa ja noin 100 kuutiota (tonnia) puhdasta vettä asukasta kohden vuodessa, ja kiinteitä jätteitä käsiteltävän noin 300 kg per asukas vuodessa. Helsingin metropolialueella tämä tarkoittaa vuosittain 500 miljoonan ruokakilon tuottamista "jossakin", ja 100 miljoonaan vesikuution juoksutusta "jostakin". Helsingin tapauksessa vesi tulee tunnelia pitkin Päijänteestä. Nykyiset metropolit ovatkin täysin fossiilienergiasta riippuvaisia, ja kipuilevat etsiessään korvaavia energianlähteitä. Tätä elintärkeätä vuorovaikutusta ympäröivien maaseutujen kanssa kaupunkien asukkaat eivät yleensä itse tiedosta.

Kestävän energiantuotannon suhteen kaupungit ovat täysin riippuvaisia ulkopuolisista alueista. Näköpiirissä olevat teknologiset ratkaisut, kuten suuret tuulipuistot ja aurinkopaneelikentät rakennetaan tyypillisesti metropolien ulkopuolelle. Energiantuotannon ekologinen jalanjälki uhkaa siis jatkossakin jäädä niiden asukkaalta piiloon, vaikka myös pienydinvoimaloita on visioitu kaupunkien energiaratkaisuina. Tämä ympäristöstä riippumattomuuden illuusio voi ilmentyä esimerkiksi metropolien haluna irtautua kansallisista politiikoista ja hallinnosta. Kaupunkilähtöinen maailma ei olisikaan kansallisvaltioiden tai niiden unionien, vaan keskenään kilpailevien kaupunkien ja pahimmillaan ympäristöjään ja globaaleja resursseja ahmivien metropolien hallitsema maailma.

Erilliseksi ymmärretystä luonnosta ammentamisen lähtökohta koskee myös kestävyysratkaisuja tarjoavaa biotaloutta. Vaikka biotalous sisältää 
ekologisen modernisaation sävyjä, se on pitkälti säilyttänyt dualistisen teollis-taloudellisen lähtökohdan. On kuitenkin hyviä perusteita esittää (kts. Horlings \& Marsden 2012), että kestävyysmuutoksen ekologinen ulottuvuus edellyttää uudenlaista ekotaloutta, eli ekosysteemiperustaisuutta tuotannossa ja siten myös paikkaperustaisuutta alueiden kehityksessä. Ekotalouden ja paikkaperustaisuuden vahvistamisen kautta maaseudun ja kaupungin suhde linkittyy uudella tavalla keskusteluun kestävyysmuutoksen toimeenpanosta.

Elintarviketeollisten tuotantoketjujen tehokkuuden näkökulmasta monet maaseudut ovat nykyisin lähinnä raaka-aineiden lähteitä. Jalostava tuotanto ja työpaikat ovat keskittyneet voimakkaasti, eikä muutokseen ole pystytty vastaamaan monipuolistamalla maaseutujen elinkeinorakennetta. Sidos maahan pitää viljelijäväestöä paikoillaan, mutta elinkeinojen monipuolisuutta ja kylien elinvoimaa pitkään jatkunut keskittyvä kehitys on laajasti heikentänyt. Samalla paikallisten palvelujen ja paikallisen tuotannon keskuksissa, maaseutukaupungeissa, väestö on jäänyt palvelujen saatavuudessa ja muun muassa asunto-omistusten arvonkehityksessä jälkeen kaupunkiseuduista.

Kriittisesti tarkastellen metropolisoituminen voidaan tulkita yhden historiallisen kehityskulun ääripäänä, josta käänne kestävämpään kehitykseen on välttämätön. Voisiko maaseudun ja kaupungin tasapainoisemman vuorovaikutuksen myötä syntyä hajautetumpaa rakennetta ja resurssiviisaampaa toimintaa? Entä jos fossiilitalouden jälkeisen talouden elinvoima kumpuaakin aiempaa monipaikkaisemmin seutukunnista maaseutukaupunkeineen ja -taajamineen?

Vaikka digitalisaatio voisi osaltaan tukea tällaista kestävyysmuutosta (sustainable transition), paikallistetun rakenteen luominen olisi kuitenkin valtaisa haaste. Vaadittava fyysinen infrastruktuuri vaatisi tiestön, sähköverkkojen, nopeiden ja luotettavien laajakaistaverkkojen rakentamista ja ylläpitoa. Toisaalta käsillä voisi olla nopeakin muutos, jos sopeutetut ratkaisut sovitetaan yhteen ilmastotavoitteiden, kiertotaloustavoitteiden sekä rakenne- ja elinvoimapoliittisten tavoitteiden kanssa. Toistaiseksi avoin kysymys on, onko ihmisillä ja yhteiskunnan erilaisilla toimijaryhmillä sosiaalipsykologisessa mielessä kyky luoda kestävyysmuutoksen edellyttämää yhteistä tietoisuutta ja politiikkaa. 


\section{Maaseudun ja kaupungin hybridiset tilat ja yhteisen hyvinvoinnin tavoite}

Siinä vaiheessa, kun luonnonvarojen ja biosfäärin rajallisuus tunnustetaan globaalisti, siitä seuraa suuntautuminen kestävyyden tielle, joka tunnustaa planeettarajat ja ympäristöllisen kestävyyden kaiken taloudellisen ja kulttuurisen kestävyyden pohjana (Stockholm Resilence Centre 2016). Tämän tien valitseminen edellyttää luopumista ekstraktiivistisesta perusoletuksesta ja nojautumista perusoletukseen, jota voisi luonnehtia ekosysteemiseksi.

Tässä lähtökohdassa ihminen ja yhteiskunnat nähdään yhtä lailla osana luontoa, kuten kanssaelävät lajit. Välttääksemme ihmisen ja luonnon dualistisen tarkastelun jatkumisen ehdotamme tälle lähtökohdalle nimeksi yhteinen hyvinvointi (One Wellbeing). Tämä käsite on läheinen aiemmin esitetyn yhteisen terveyden (One Health) käsitteen kanssa (kts. Sukura \& Hänninen 2016), mutta haluamme korostaa sen laajentamista yhteiskunnallisen ja ekologisen kestävyyden ajatukset integroivaksi käsitteeksi.

Yhteinen hyvinvointi asettaa vallitsevassa kestävyysajattelussa esille tuodut bio- ja kiertotalouden tarjoamat "ratkaisut" uuteen valoon siten, että osa niistä on vaadittavia, mutta yhdessäkään ne eivät muodosta riittävää "ratkaisua" kestävyysmuutokseen.

Koska materiaalikierroilla, erityisesti biotalouden kierroilla on mittakaavansa, ne ovat teknisesti todennäköisesti helpoiten, tai jopa ainoastaan toteutettavissa nykyistä hajautuneempina malleina, paikallistetun tuotannon ja kulutuksen järjestelmien verkostoina.

Paikallisten ratkaisujen vahvuutena voidaan nähdä myös se, että niiden kautta ihmiset ja yhteisöt pääsevät paitsi osallisiksi niiden tuomasta hyvinvoinnista, myös todennäköisesti paremmin kantamaan vastuutaan ekosysteemien toiminnasta, yhdestä ja ylilajisesta yhteisestä hyvinvoinnista. Vaikka yhteinen hyvinvointi edellyttäisi keskittyneen tuotannon ja kulutuksen osittaista purkautumista, kaupunkikeskustat säilyttäisivät todennäköisesti roolinsa verkostojen, palvelujen, kaupankäynnin ja hallinnon solmukohtina.

Päinvastoin kuin nykyisessä talousjärjestelmässä, joka hämärtää maaseutujen suhdetta kaupunkeihin, yhteisen hyvinvoinnin taloudessa kaupungit solmivat elävän ja elinvoimaa ylläpitävän suhteen ympäröivien 
maaseutujen paikallisiin toimijoihin ja yhteisöihin. Kaupungit rakentuisivat kestävällä tavalla riippuvaisiksi ympäristöistään, jota ne osaltaan vastavuoroisesti palvelevat.

Yhteisen hyvinvoinnin tavoittelu edellyttää siis maaseutujen ja kaupunkien uudistavan vuorovaikutuksen sisällyttämistä kestävyysmuutosta koskevaan keskusteluun. Tässä yhdymme muun muassa Marsdenin \& Sonninon (2012) esittämään ajatukseen hylätä maaseudun ja kaupungin välinen dikotomia sekä synnyttää ja hyödyntää uudenlaisia, hybridisiä maaseudun ja kaupungin välisiä suhteita, jotka käytännössä tukevat kestävyystavoitteiden toteutumista, kuten esimerkiksi lisäävät ruokaturvallisuutta, muutoskestävyyttä ja ruokaketjun monimuotoisuutta (ks. myös Lerner \& Eakin 2011).

Tuotanto- ja kulutuskeskeisestä elämäntavasta enenevästi luopuvat, hyvinvointia ja kestävää kehitystä korostavat sukupolvet voivat rakentaa näitä hybridisiä tiloja ja ratkaisuja "solmiakseen rauhan luonnon kanssa" (UNEP 2021). Esimerkiksi käy osallistuminen paikallisten ruokajärjestelmien toimintaan, jossa ekosysteemiyhteydet ja maaseudun ja kaupungin keskinäisriippuvuus konkretisoituu. Ainevirta-, ekosysteemi ja eliöyhteisöjen tasoilla avautuu näin mahdollisuus uudenlaisille tavoille toteuttaa

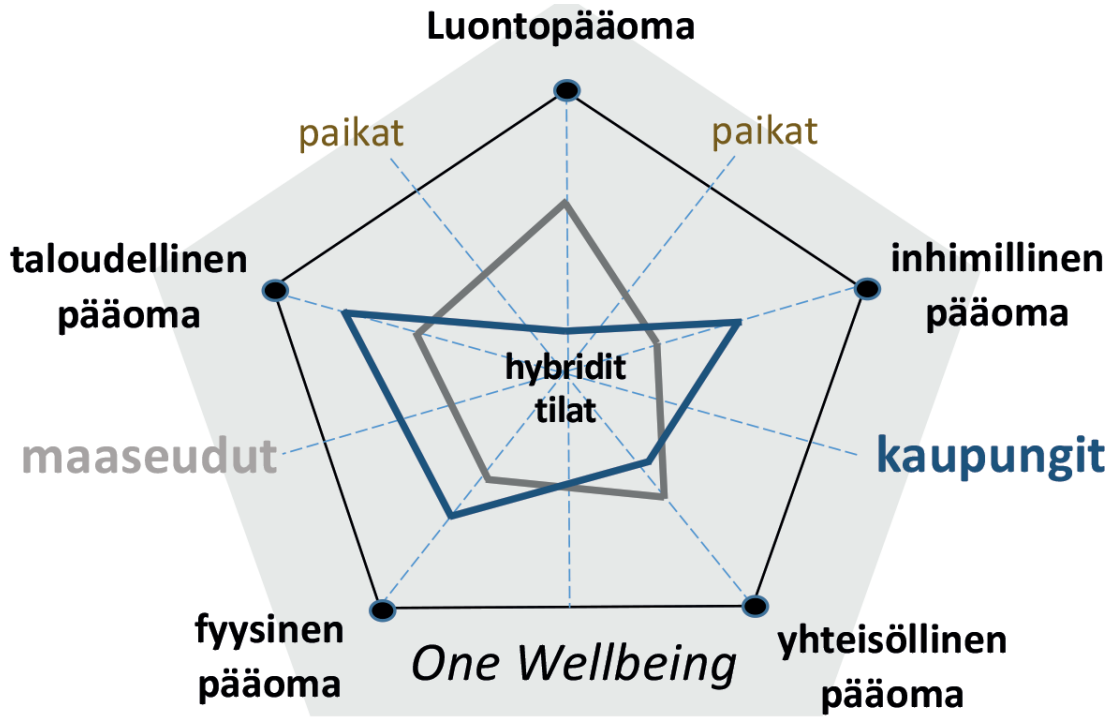

Kuvio 1: Maaseutujen ja kaupunkien vuorovaikutuksena syntyvän yhteisen hyvinvoinnin (One Wellbeing) pääomien ja paikallisuuksien tilallinen asetelma. 
yhteistä ekososiaalista ja inhimillistä hyvinvointia. Tämä voi tarkoittaa myös kiertotalouden periaatteiden paikallista toteuttamista symbioottisten tuotannon mallien kautta (ks. Helenius ym. 2021).

Maaseudun ja kaupungin väliset hybridiset tilat voidaan siis ymmärtää erilaisten paikallisuuksien välisiksi uudenlaisiksi vuorovaikutuksen käytänteiksi, jotka sitovat maaseudun ja kaupungin pääomia itseensä päämääränä yhteinen hyvinvointi (Kuvio 1). Nämä vuorovaikutuksen hybridiset tilat tarjoavat mahdollisuuden synnyttää uutta elinvoimaa ja hyvinvointia kutomalla yhteyksiä ihmisten, toimijaryhmien ja pääomien välille.

\section{Lähteet}

Appelsin, Ulla 2021. Ulla Appelsinin kommentti: Ministeri Ohisalo, entä jos meille tulee nälkä? Sekä artikkeliin liittyvät kommentit (867). Ilta-Sanomat 13.8.2021, verkkolehti. Saatavissa: https://www.is.fi/kotimaa/art-2000008191040.html [Käytetty 7.12.2021].

Eerola, Antero 2021. Kepun nuori emäntä iltalypsyllä. Kansan Uutiset. Blogit. 27.4.2021. Saatavissa: https://blogit.kansanuutiset.fi/merkintoja-suomesta-ja-maailmasta/ kepun-nuori-emanta-iltalypsylla/ [Käytetty 7.12.2021].

Enbuske, Tuomas 2017a. "Miksi maalaiset ovat tyhmempiä kuin kaupunkilaiset". IL blogit 10.3.2017. Saatavissa: https://www.iltalehti.fi/uutiset/a/201703102200083823 [Käytetty 7.12.2021].

Enbuske, Tuomas 2017b. Kaupunkilaiset ovat tyhmempiä kuin maalaiset. IL blogit 17.3.2017. Saatavissa: https://www.iltalehti.fi/uutiset/a/201703172200087490 [Käytetty 7.12.2017].

Haapamatti, Kirsi 2015. Maalaismukulat vs. kaupunkilaiskersat. Maaseudun Tulevaisuus 24.6.2021. Saatavissa: https://www.maaseuduntulevaisuus.fi/suomalainenmaaseutu/maalaismukulat-vs-kaupunkilaiskersat-1.124307 [Käytetty 7.12.2021].

Hyvä taloudenpito hallituksen tärkein tehtävä 2020. Kaleva 24.4.2021. Saatavissa: https:// www.kaleva.fi/saarikko-puoluevaltuustossa-hyva-taloudenpito-hall/3547954 [Käytetty 7.12.2021].

Junkkari, Marko 2020. Uusimaa sai identiteetin - joka kohta taas katoaa. HS Viikko Helsingin sanomien parhaat jutut 17.-23.4.2020. Sivu A3.

Karvala, Kreeta 2015. "Tällainen on "kepulandia". Iltalehti. Saatavissa: https://www.iltalehti. fi/eduskuntavaalit-2015/a/2015042019553749 [Käytetty 7.12.2021].

Koivula, Jukka 2021. "Kyse ei ole mistään iltalypsystä vaan valtion talouden hoidosta", Honkonen perustelee keskustan tiukkaa linjaa kehysriihineuvotteluissa. Maaseudun Tulevaisuus 23.4.2021. Saatavissa: https://www.maaseuduntulevaisuus.fi/politiikka/ artikkeli-1.1378333 [Käytetty 7.12.2021].

Maaseutu ei ole kehityksen jarru 2015. Pääkirjoitus - Maaseudun Tulevaisuus 22.5.2015. Saatavissa: https://www.maaseuduntulevaisuus.fi/puheenaiheet/paakirioitus/ maaseutu-ei-ole-kehityksen-jarru-1.119877 [Käytetty 7.12.2021]. 
Pelkonen, Linda 2018. Maaseutu vastaan kaupunki - teennäinen jako vai todelliset kuplat? Uusi Suomi Blogit 30.11.2018. Saatavissa: https://puheenvuoro.uusisuomi.fi/ lindapelkonen/264967-maaseutu-vastaan-kaupunki-teennainen-jako-vai-todellisetkuplat/ [Käytetty 7.12.2021].

Pääkaupunki elättää muun Suomen 2009. Iltasanomat - Taloussanomat 18.1.2009. Saatavissa: https://www.is.fi/taloussanomat/art-2000001611645.html [Käytetty 7.12.2021].

Rummukainen, Anu 2015. Näin keskusteltiin karhun kaadosta: maalaiset huutavat apua liian herkästi ja kaupunkilaiset eivät tiedä mistä puhuvat. Yle - Uutiset. 13.3.2015. Saatavissa: https://yle.fi/uutiset/3-7865070 [Käytetty 7.12.2021].

Saarikko puoluevaltuustossa: Hyvä taloudenpito hallituksen tärkein tehtävä 2021. Kaleva 24.4.2021. Saatavissa: https://www.kaleva.fi/saarikko-puoluevaltuustossa-hyvataloudenpito-hall/3547954 [Käytetty 7.12.2021].

\section{Kirjallisuus}

Helenius, Juha, Sophia Hagolani-Albov \& Kari Koppelmäki 2021. Ruokajärjestelmän kestävyysmuutos. Elinvoimaa agroekologisista symbiooseista. Maaseutututkimus 29 / 1. 84-105.

Horlings, Lummina G. \& Terry K. Marsden 2012. Exploring the "New Rural Paradigm" in Europe: Eco-economic strategies as a counterforce to the global competitiveness agenda. European Urban and Regional Studies 21: 4. https://journals.sagepub. com/doi/10.1177/0969776412441934

Koste, Otto-Wille, Panu Lehtovuori, Aleksi Neuvonen \& Kaisa Schmidt-Thomé 2020. Miksi Suomen kaupungistuminen jatkuu? Argumentteja keskusteluun Suomen kaupungistumisen syistä 2020-luvulla. URMI Politiikkapaperi 2020:1. https://www. demoshelsinki.fi/wp-content/uploads/2020/02/julkaisu-miksi-suomenkaupungistuminen-jatkuu-.pdf [Luettu 26.8.2021].

Lerner, Amy M. \& Hallie Eakin 2011. An obsolete dichotomy? Rethinking the rural-urban interface in terms of food security and production in the global south. The Geographical Journal, Vol. 177/ 4. 311-320.

Marsden, Terry \& Roberta Sonnino 2012. Human health and wellbeing and the sustainability of urban-regional food systems. Current Opinion in Environmental Sustainability 4. 427-430.

Masuda Jeffrey R. \& Theresa Garvin 2008. Whose Heartland? The politics of place in a rural-urban interface. Journal of Rural Studies 24/1. 12-123.

Moisio, Sami 2018. Geopolitics of the Knowledge-Based Economy. Regional Studies Association. Routledge.

Poranen, Katarina 2013. "Etelän medialle keskusta on helppoa riistaa" Tulkintoja etelän mediasta: poliitikkojen ja toimittajien käsityksiä sekä kehysanalyysi keskustapuolueen kesäkuun 2010 puoluekokouksen julkisuudesta Aamulehdessä, Helsingin Sanomissa ja llkassa. Tampereen yliopisto. Tiedotusopin pro gradu.

Pyysiäinen, Jarkko \& Hilkka Vihinen 2020. Maaseutubarometri 2020. Tutkimusraportti osa 1. Luonnonvarakeskus. Saatavissa: https://www.maaseutupolitiikka.fi/uploads/ MANE-raportit/Maaseutubarometri-taitettu-diasetti-osa-1-julkaisu-FINAL-17062020paivitetty.pdf [Luettu 7.12.2021]. 
Rakennusteollisuus 2021. Tilastot ja suhdanteet. https://www.rakennusteollisuus.fi/ Tietoa-alasta/Talous-tilastot-ja-suhdanteet/ [Luettu 4.12.2021].

Sukura, Antti \& Marja-Liisa Hänninen 2016. One Health - inmisten, eläinten ja ympäristön yhteinen terveys. Lääketieteellinen aikakauskirja Duodecim. 132 (13). One Health ihmisten, eläinten ja ympäristön yhteinen terveys (duodecimlehti.fi) [Luettu 1.12.2021].

Stockholm Resilence Centre 2016. How food connects all the SDGs. https://www. stockholmresilience.org/research/research-news/2016-06-14-how-food-connectsall-the-sdgs.html [Luettu 26.8.2021].

Tervonen, Miika 2014. Historiankirjoitus ja myytti yhden kulttuurin Suomesta. Teoksessa Markkola, Pirjo, Hanna Snellman \& Ann-Catrin Östman (toim.). Kotiseutu ja kansakunta. Miten suomalaista historiaa on rakennettu. Suomalaisen Kirjallisuuden Seura. Helsinki. 137-162.

UN Habitat 2020. Global State of Metropolis 2020 - Population Data Booklet. UN-Habitat, Nairobi. https://unhabitat.org/sites/default/files/2020/09/gsm-population-databooklet-2020 3.pdf [Luettu 26.8.2021]. 